\title{
Cikkismertetés: A gyermekkori elhízás rendszeralapú megelőzése - N3.0 a gyakorlatban
}

Article review: System-based prevention of childhood obesity - N3.0 in practice

Ismertető:

Ismertetett cikk: Garcia, L., Hunter, R. F., de la Haye, K., Economos, C. D., \& King, A. C. (2021). An action-oriented framework for systems-based solutions aimed at childhood obesity prevention in US Latinx and Latin American populations. Obesity reviews: an official journal of the International Association for the Study of Obesity, e13241. Advance online publication. doi: $10.1111 /$ obr.13241

Kulcsszavak: $\quad$ megelőzés; elhízás; gyerekek; rendszerszemlélet; gyakorlat

Keywords: $\quad$ prevention; obesity; children; systems thinking; practice

Beküldve: 2021. 06. 30., doi: $10.24365 /$ ef.v62i3.6109

\section{BEVEZETÉS}

A szerzők kiindulópontja az volt, hogy a különféle beavatkozások ellenére növekszik a gyermekkori elhízás az Amerikai Egyesült Államok (USA) latin-amerikai származású és Latin-Amerika lakosságának körében. Ez a tendencia arra utal, hogy olyan tartós és összetett problémával kell szembenézni, ami az egészségügyre és más szektorokra is komoly terhet ró. A komplex és az eddigi megoldásoknak ellenálló probléma hátterében több szinten, sokféle befolyásoló tényező és társadalmi szereplő egymással dinamikus kölcsönhatása azonosítható. Emiatt kedvezőbb eredményeket csakis a rendszertudomány elméletének és módszereinek alkalmazásával lehet elérni.

A rendszertudomány egy interdiszciplináris terület, amely a rendszerek - az egymástól függő elemekből álló integrált egészek — tulajdonságainak tanulmányozásával foglalkozik. A komplex adaptív rendszerek a rendszerek speciális esetei: sok olyan elem vagy komponens alkotja őket, amelyek végletesen összefonódnak, kölcsönhatásba lépnek egymással, kismértékü, vagy egyáltalán nem létező központi koordináció vagy irányítás mellett. Ezek olyan mintákat és működési módokat hoznak létre, melyeket az egyes részelemek nem jelenítenek meg, és amelyek a rendszer környezetében bekövetkező változásokra reagálva alkalmazkodnak.

A gyermekkori elhízás szintje az USA latin-amerikai származású és a latin-amerikai népességben úgy fogalmazható meg, mint egy olyan komplex adaptív rendszer eredménye, amely magában foglalja az élelmiszer-, iskola- és közlekedési rendszereket, a szociokulturális és környezeti hatásokat, valamint számos más tényezőt, amelyek egymással kölcsönhatásban alakítják az energiabevitelt és -felhasználást.

Például, a komplex adaptív rendszerek elemei azonosíthatók a gyermekkori elhízás megelőzésével kapcsolatos olyan sikeres latin-amerikai kezdeményezésekben, mint a cukrozott üdítők és az egészségtelen ételek megadóztatása Mexikóban, az élelmiszerek címkézése Chilében és Ecuadorban, a transzzsírsavak csökkentése az argentin élelmiszerellátásban, valamint a Ciclovías Recreativas ii néven ismert nyitott utcák program Kolumbiában. Ezek az elemek magukban foglalták a politika végrehajtását vagy folytatását elősegítő vagy akadályozó visszacsatolási hurkokat; a tudás és a viselkedés elterjedését befolyásoló társadalmi hálózatok jellemzőinek kiaknázását; a rendszerekben bekövetkező radikális változások elősegítését a fordulópont elérésekor; valamint a történelmi kontextus és a rendszer elemei közötti kölcsönhatásból eredő

\footnotetext{
' Latin-Amerika megnevezés alatt Mexikót, Közép-Amerikát, a Karib-térséget és Dél-Amerikát értjük.

ii Latin-Amerikában így nevezik azt az eseményt, amikor ideiglenesen elzárnak utcákat az autó-motor forgalom elől, így teremtve biztonságos és kellemes környezetet a kerékpárosok, gyalogosok, kocogók vagy görkorcsolyázók számára.
} 
közösségi minták és viselkedésmódok figyelembevételét.

A komplex rendszerek stabilizálódnak, és a külső, zavaró hatásokat semlegesítve képesek fenntartani korábbi állapotukat. Ez azt jelenti, hogy a rendszer átalakítására irányuló erőfeszítések a rendszer "helyreállító" reakcióját váltják ki, ami a probléma kezelésének gyakori kudarcához vezet, ismertebb nevén a rendszer ellenáll a változásnak. A népegészségügy komplex problémáival kapcsolatos jelenlegi szakirodalom nagy része inkább elméleten, mint gyakorlati alkalmazásokon alapul. Az interdiszciplináris és multiszektoriális csoportok (pl. népegészségügyi szakemberek, más ágazatok szakemberei, értékelők, kutatók, közösségi vezetők, döntéshozók és érdekeltek) számára kevés, a gyermekkori elhízás kezelésére összpontosító rendszeralapú iránymutatás érhető el. Ez a közlemény egy olyan cselekvésorientált keretrendszert mutat be, amely a gyermekkori elhízás megelőzésére irányuló prevenció tervezése, megvalósítása, értékelése és a teljes rendszer szintjén bekövetkező változások fenntartása érdekében beépíti és alkalmazza a rendszertudomány elméletét és módszertanát.

\section{RENDSZERSZINTŰ VÁLTOZÁST CÉLZÓ, GYAKORLATORIENTÁLT KERETRENDSZER A GYERMEKKORI ELHÍZÁS MEGELŐZÉSÉRE}

\begin{abstract}
A bemutatandó gyakorlatorientált keretrendszer magában foglalja azt a hat szükséges tevékenységet, amelyek tartósan megváltoztatják a gyermekkori elhízást tápláló és fenntartó viszonyokat. A keretrendszert felvázoló 1 . ábra az egyes tevékenységeket egymásba akaszkodó fogaskerékként jelöli, körülöttük láthatók azok az alapelvek, amikre az ábrázolt tevékenységek épülnek.iii A feltüntetett alapelveket a szerzők a cikkben pontokba szedve kifejtik. A keretrendszer gyakorlatban való alkalmazását segíti a 2. ábra és a 3. ábra, mert mind a hat tevékenységet, azok eredményeit, valamint az alkalmazott módszereket, elméleteket részletezik.
\end{abstract}

1. ábra: A gyermekkori elhízás rendszerszintű visszaszorítását célzó gyakorlatorientált keretrendszer

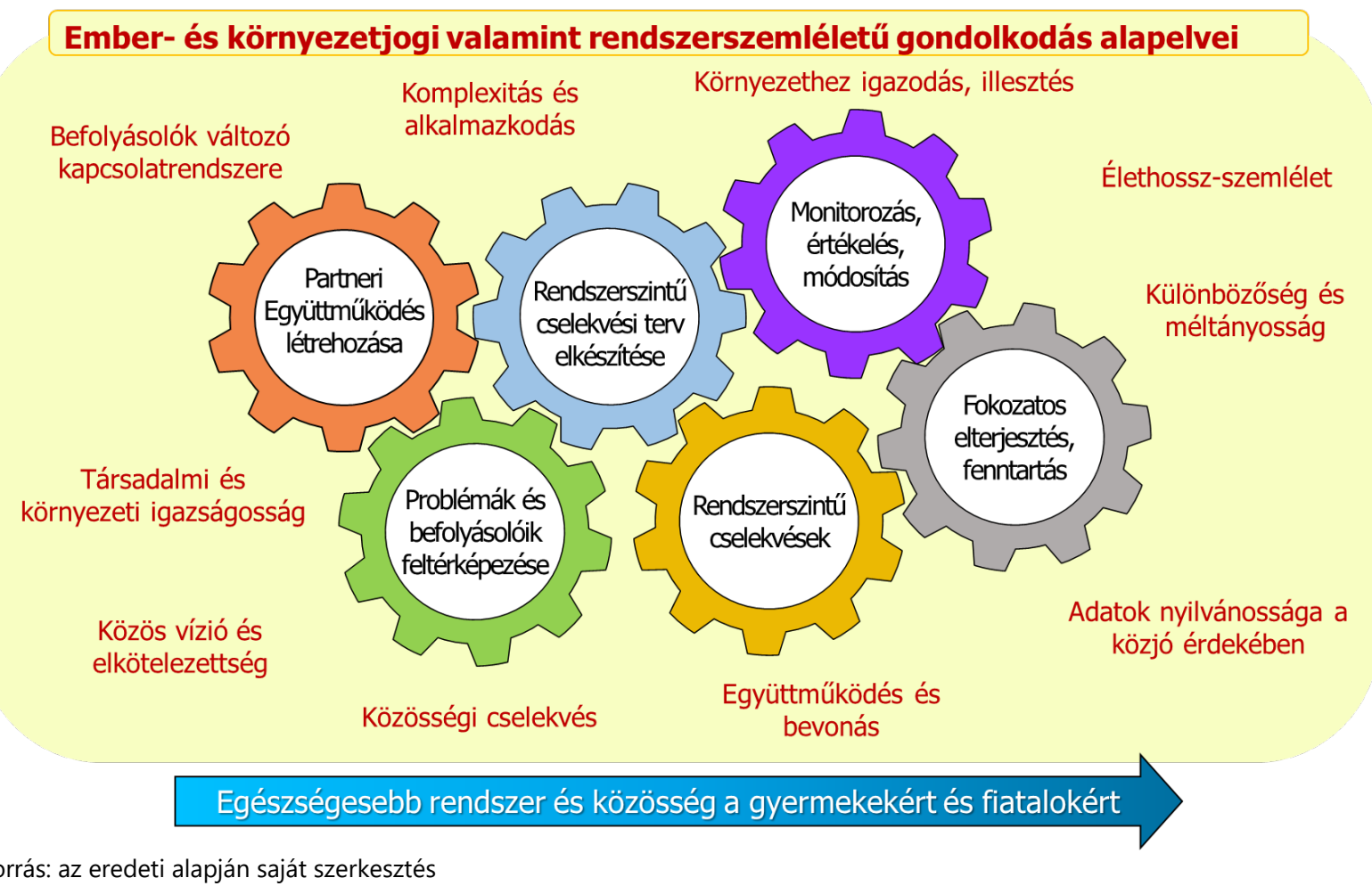

\footnotetext{
iii Az első tevékenységben jelölt Partneri Együttműködések a közösségi problémák komplexitását felismerő és a megoldáshoz a részvételiséget elengedhetetlennek tartó népegészségügyi kezdeményezések sajátos szervezetei. Részletesebben erről Girán és mtsai. (2021) valamint Vitrai és mtsai. (2021) jelentettek meg közleményeket.
} 
2. ábra: A keretrendszer egyes cselekvési lépéseinek intézkedései és várható eredményei

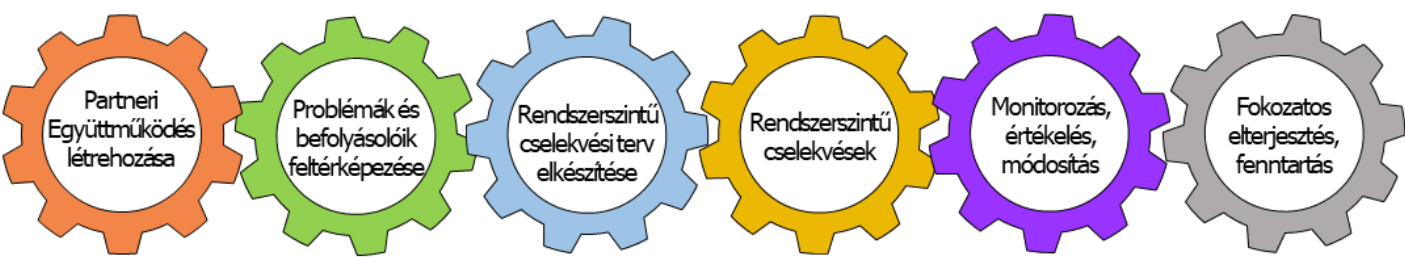

\begin{tabular}{|c|c|c|c|c|c|c|}
\hline Tevékenységek & $\begin{array}{l}\text { - Az érdekelt felek és } \\
\text { kapcsolatok azonosítása } \\
\text { - Koalíió összeállitása } \\
\text { - Bizalom, tisztelet és } \\
\text { kohézió kiépítése } \\
\text { - Közös elvekés törekvések } \\
\text { meghatározása }\end{array}$ & $\begin{array}{l}\text { - A probléma } \\
\text { megfogalmazása } \\
\text { - A problémában szerepet } \\
\text { játszó tényezôk, } \\
\text { fogalmak, azok } \\
\text { összeuággései, valamint } \\
\text { ezek idôbeli iáltozásának } \\
\text { feltérképezése } \\
\end{array}$ & $\begin{array}{l}\text { - Közös jövő́kép kialakitása } \\
\text { - A lehetséges cselekvésiés } \\
\text { ellenállási pontok } \\
\text { azonositása } \\
\text { - A bizonyitékok, } \\
\text { tanulságokés syakorlatok } \\
\text { feltérképezése és } \\
\text { áttekintése } \\
\text { - Intézkedések közös } \\
\text { megtervezése } \\
\text { - Az erốforrásokés az } \\
\text { elszámoltathatóság } \\
\text { biztositása } \\
\text { - Megállapodás a } \\
\text { végrehajtási ütemtervrốl }\end{array}$ & $\begin{array}{l}\text { - Koordinált intézkedések } \\
\text { végrehaitása több } \\
\text { ágazatot átfogó csoport } \\
\text { által } \\
\text { - Aktiv szerepvállalás a } \\
\text { rendszerben való elérés } \\
\text { és elfogadás növelése } \\
\text { érdekében }\end{array}$ & $\begin{array}{l}\text { - Többoldalú adatgyứtés } \\
\text { - Az adatokelemzése és } \\
\text { értelmezése } \\
\text { - Az eredmények } \\
\text { kommunikálása } \\
\text { - Kollektiv tanulságok } \\
\text { levonása } \\
\text { - A megerốsitendó } \\
\text { területek azonositása } \\
\text { - A végrehajtásiütemterv } \\
\text { kiigazítása }\end{array}$ & $\begin{array}{l}\text { - Az alkalmazkodási } \\
\text { fordulópontokés az } \\
\text { alkalmazkodási utak } \\
\text { meghatározása } \\
\text { - Forrásokés } \\
\text { elszámoltathatóság } \\
\text { biztositása } \\
\text { - Az önszervezốdés és a } \\
\text { döntéshozatal } \\
\text { decentralizációjának } \\
\text { lehetôvététele }\end{array}$ \\
\hline Eredmények & $\begin{array}{l}\text { - Partnerek szilárd } \\
\text { koalíciója } \\
\text { - Kezdeményezett } \\
\text { közösségi kapacitás- } \\
\text { Vezetés és irányitás } \\
\text { - Stratégiai ütemterv } \\
\text { - Kollektiv tanulást, } \\
\text { alkotást és cselekvést } \\
\text { öszzönzố kultúra és } \\
\text { környezet }\end{array}$ & $\begin{array}{l}\text { - A problématér közösen } \\
\text { generált modellje } \\
\text { - A rendszer közös mentális } \\
\text { modellje } \\
\text { - Annak megértése, hogy a } \\
\text { rendszer hogyan fejlödött } \\
\text { eddig, és milyen } \\
\text { mechanizmusok és } \\
\text { események hatására }\end{array}$ & $\begin{array}{l}\text { - Jövökép } \\
\text { A változás elmélete } \\
\text { összzehohangolt, kollektiv, } \\
\text { összessége } \\
\text { - Végrehajésések }\end{array}$ & $\begin{array}{l}\text { - Változások a probléma } \\
\text { mozgatórugóiban, } \\
\text { valaminta rendszer } \\
\text { formájában és } \\
\text { mứködésében } \\
\text { - A célközönség általi } \\
\text { elfogadás } \\
\text { - Új szookások elfogadása } \\
\text { - Új társadalmi normák }\end{array}$ & $\begin{array}{l}\text { - A végrehajtás nyomon } \\
\text { kōvetése } \\
\text { Tanulságok arról, hogya } \\
\text { rendszer hogyan reagála } \\
\text { változásokra, miért és } \\
\text { kinek a számára } \\
\text { - Frissitett közös mentális } \\
\text { modell } \\
\text { - A végrehajtásiütemterv } \\
\text { hangolása és kiigazítása }\end{array}$ & $\begin{array}{l}\text { - A rendszer új formája és } \\
\text { funkciója } \\
\text { - Uuj szokásokés normák } \\
\text { beépítése } \\
\text { - A nem kivánt állapotba } \\
\text { valóvisszatérés } \\
\text { elkerülésére és a nem } \\
\text { szándékelt } \\
\text { kôvetkezmények } \\
\text { ellenôrzésére szolgáló } \\
\text { folyamatok bevezetése }\end{array}$ \\
\hline
\end{tabular}

Forrás: az eredeti alapján saját szerkesztés

3. ábra: Példák az egyes cselekvési lépések módszereire és megközelítéseire

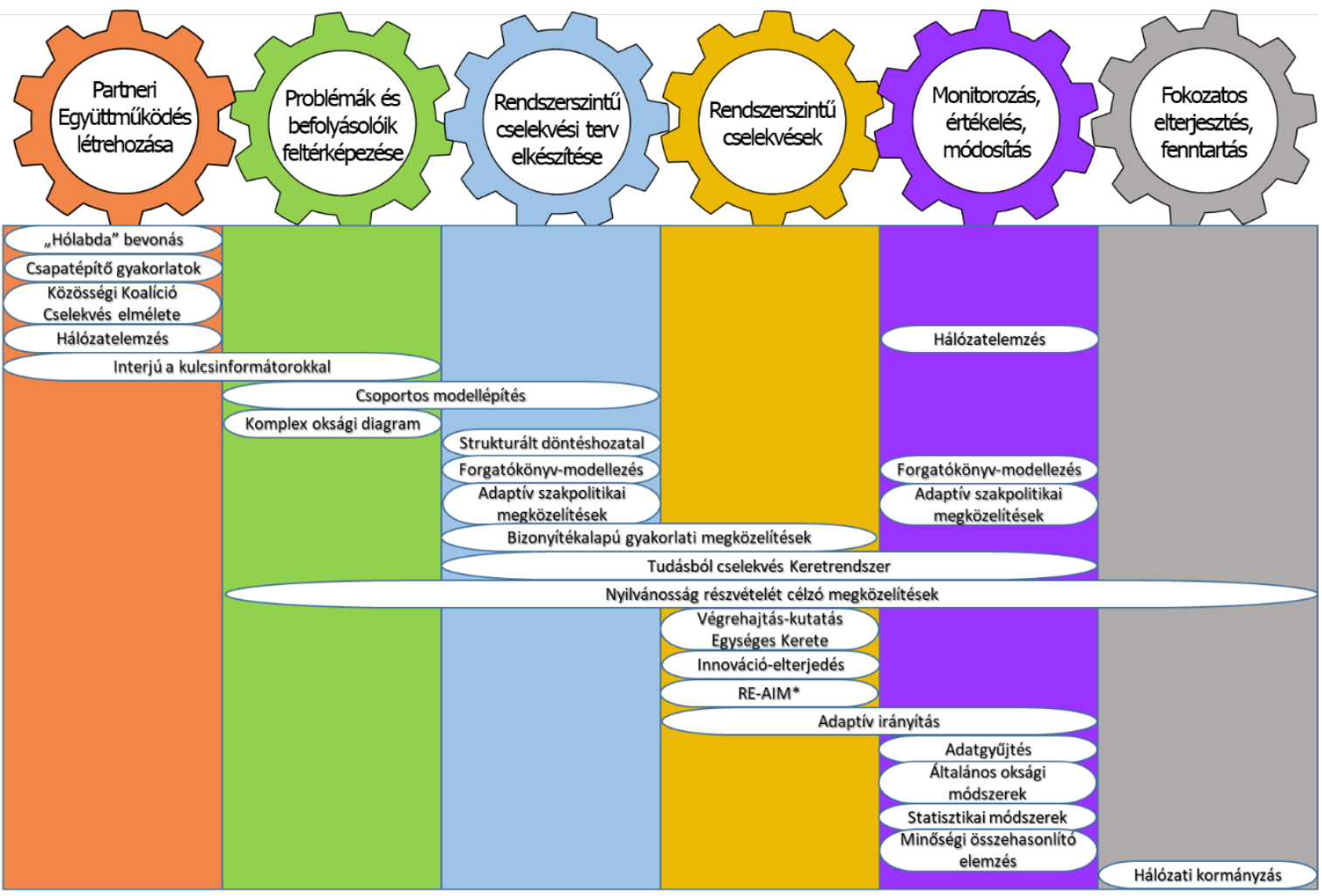

*RE-AIM: Elérés, hatékonyság, elfogadás, megvalósitás és fenntartás keretrendszer Forrás: az eredeti alapján saját szerkesztés 
A gyakorlati megvalósítás hat tevékenysége az eredeti cikkben részletesen bemutatásra kerül.

A szerzők közleményük végén a gyermekelhízás csökkentését célzó rendszeralapú programok megvalósításának USA-beli nehézségeit veszik számba a szakirodalom áttekintése alapján. A programok végrehajtását szerintük a következők akadályozzák:

a) a finanszírozási források és ösztönzők hiánya a rendszertudományi megközelítések alkalmazásához;

b) a rendszerindikátorok és -modellek megértésének vagy az abbéli jártasság hiánya, a kutatások leegyszerűsített (nem kontextuális) modelljeinek, mint pl. a randomizált kontrollvizsgálatok és a laboratóriumi alapú vizsgálati tervek használata;

c) a rendszeralapú tervezés és értékelés előmozdítására szánt idő és elkötelezettség hiánya;

d) a megjósolható (feltételezett) és gyakran rövidtávú, objektíven mérhető eredmények preferálása;

e) a komplexitás túlzott leegyszerűsítése olyan módon, amely aláássa a kontextuális megközelítéseket; és

f) olyan kutatási és tudományos rendszerek (finanszírozási határidők, tudományos jutalmazási rendszerek, kinevezés és előléptetés), amelyek a nem rendszerorientált kutatási kérdéseket és vizsgálati terveket támogatják.
Megoldásként a szerzők kapacitásfejlesztést javasolnak a kutatásokban, a közösségekben, a szakpolitikában és a helyi programok megvalósításában. A hagyományos, elszigetelt megközelítés helyett a rendszerszemlélet és az érintettek bevonása vezethet csak eredményekhez a gyermekelhízás visszaszorításában.

\section{KÖVETKEZTETÉSEK}

Ez a gyakorlatorientált megközelítés a gyermekkori elhízás kezelésére a rendszertudomány segítségével új utat nyit a holisztikus és interdiszciplináris kutatás és tevékenységek felé. A folyamatosan gyarapodó bizonyítékok támogatják a rendszeralapú, gyakorlatorientált keretrendszer alkalmazását a gyermekkori elhízás csökkentése érdekében, tekintettel az eddig elért korlátozott eredményekre. Az ágazatközi és interdiszciplináris együttműködésekre, képzési lehetőségekre, a rendszertudományok befogadására nyitott kutatási kultúrára és a keretrendszer alkalmazását támogató finanszírozási mechanizmusokra van szükség a népegészségügyi erőfeszítések előmozdításához, hogy megállítsák az elhízás növekedését az USA latin-amerikai származású lakosainak körében és Latin-Amerika népességében, továbbá előmozdítsák az egészségegyenlőséget.

\section{TANULSÁGOK A HAZAI SZAKEMBEREK SZÁMÁRA}

Az ismertetett írás egy innovatív, de egyben gyakorlati megközelítést javasol a gyermekelhízás eredményes visszaszorítására. Az újszerűség az elhízás problémájának komplex értelmezésében és az érintettek megoldásba történő bevonásában ragadható meg. Erről az új népegészségügyi szemléletről, amit Magyarországon N3.0-ként jelölnek (Vitrai, 2019), jelentek meg már közlemények az Egészségfejlesztés folyóirat hasábjain (Girán és mtsai, 2021; Vitrai és mtsai, 2021). A hazai népegészségügy helyzetéről (Túri és mtsa, 2018), megújitásának szükségességéről pedig Vitrai (2019) vitacikkében érvelt ugyanitt. Adatok és érvek sokasága szól tehát a mellett, hogy a magyar lakosság egészségének javításához a népegészségügyben újszerű megközelítés szükséges, és ehhez az ismertetett cikk gyakorlati lépései kiválóan hasznosíthatók. A leírtak gyakorlati alkalmazásának feltétele az erre felkészített népegészségügyi szakemberek mellett a komplex beavatkozásokat támogató népegészségügyi intézményrendszer a szükséges finanszírozással együtt. 


\section{HIVATKOZÁSOK}

Girán J., Kollányi Zs., Nemesrévi M., Pipicz M., Sándor J., Somhegyi A., Terebessy A., Tóth G., Várfalvi M., Várfi M., \& Vitrai J. (2021). Útmutató a gyermekek egészségének javítására megalakuló partneri együttműködés számára. Egészségfejlesztés, 62(1), 95-200. doi: 10.24365/ef.v62i1.717

Túri G., Horváth K., Kasza K., \& Csizmadia P. (2018). Magyarország népegészségügyi rendszere és egészségfejlesztéssel foglalkozó szervezetei. Egészségfejlesztés, 59(2), 62-68. doi: 10.24365/ef.v59i2.265

Vitrai J. (2019). Vitaindító: Miért és hogyan kellene a hazai népegészségügyet megújítani? Egészségfejlesztés, 60(2), 3-5. doi: $\underline{10.24365 / \text { ef.v60i2.461 }}$

Vitrai J. (2019). Cikkismertetés: Népegészségügy 3.0. Egészségfejlesztés, 60(4), 46-51. doi: 10.24365/ef.v60i4.500

Vitrai J., Bíró É., Girán J., Kollányi Zs., Pipicz M., Somhegyi A., \& Várfalvi M. (2021). Milyen legyen a népegészségügy legújabb iránya? Vitaindító az új népegészségügyi szemlélet sajátosságairól. Egészségfejlesztés, 62(1), 81-94. doi: $10.24365 /$ ef.v62i1.716

Információk a szerzőről:

Vitrai József, független népegészségügyi szakértő, vitrai.jozsef@gmail.com 